\title{
AÇÃO DO FLÚOR DISSOLVIDO EM CHUVA SIMULADA SOBRE A ESTRUTURA FOLIAR DE PANICUM MAXIMUM JACQ. (COLONIÃO) E CHLORIS GAYANA KUNTH. (CAPIM-RHODES) - POACEAE ${ }^{1}$
}

\author{
Alba Lucilvânia Fonseca Chaves ${ }^{2}$ \\ Eldo Antônio Monteiro da Silva² \\ Aristéa Alves Azevedo ${ }^{2}$ \\ Marco Antonio Oliva Cano ${ }^{2}$ \\ Kiyoshi Matsuoka ${ }^{3}$
}

Recebido em 21/11/2000. Aceito em 23/03/2002.

\begin{abstract}
RESUMO - (Ação do flúor dissolvido em chuva simulada sobre a estrutura foliar de Panicum maximum jacq. (colonião) e Chloris gayana kunth. (capim-rhodes) - Poaceae) Panicum maximum e Chloris gayana foram submetidas à chuvas simuladas com soluções de fluoreto de potássio $\left(15 \mathrm{mg} \mathrm{ml}^{-1}\right)$ com objetivo de identificar as injúrias causadas pelo flúor $\left(\mathrm{F}^{-}\right)$, como poluente atmosférico, na estrutura da lâmina foliar e fornecer subsídios para a seleção de características diagnósticas a serem utilizadas na bioindicação. Os principais sintomas foram clorose e necrose, principalmente no ápice e margens das lâminas. Nos cortes transversais, quatro tipos de alterações causadas pelo flúor são relacionadas: redução do número, tamanho e arranjo dos cloroplastos; necrose dos tecidos principalmente nas margens das folhas; erosões na superfície da folha e hipertrofia das células. Em C. gayana, no entanto, não foram observadas as alterações nos cloroplastos e os outros sintomas foram bem mais discretos que em P. maximum. A ocorrência de compostos fenólicos foi registrada pela coloração com fucsina em todas as regiões da lâmina onde foram observadas lesões. Ao microscópio eletrônico de varredura foi observado o achatamento e formação de concavidades nas paredes externas das células. Este experimento confirma a maior sensibilidade de P. maximum ao flúor e revela algumas características anatômicas de C. gayana que, entre outros fatores, podem estar contribuindo para a maior resistência desta espécie a este poluente.
\end{abstract}

Palavras-chave - Anatomia, Poaceae, bioindicadores, flúor, poluição

\begin{abstract}
The action of dissolved fluoride in artificial rain on leaf structure of Panicum maximum Jacq. (colonião) and Chloris gayana Kunth. (capim-rhodes) - Poaceae) P. maximum and C. gayana were treated with potassium fluoride artificial rain $\left(15 \mathrm{mg} \mathrm{ml}^{-1}\right)$ to identify injury caused by fluoride $(\mathrm{F})$, as an atmospheric pollutent, on the leaf structure of these two species, providing diagnostics characteristics for plant selection to be used as
\end{abstract}

\footnotetext{
${ }^{1}$ Tese de mestrado financiada pela Capes

${ }^{2}$ Departamento de Biologia Vegetal - UFV

${ }^{5}$ Departamento de Fitopatologia - UFV
} 


\begin{abstract}
bioindicators. The observed symptons were clorosis and necrosis in the leaf blade. Four types of cell alterations were observed in transversal sections: reductions of number, size and chloroplasts disposition; necrosis of tissues in the leaf; leaf surface erosions and cells hypertrophy. In C. gayana chloroplast alterations were not observed and the other symptoms were less evident. Phenolic compounds were registered in the regions where lesions occurred. In the scanning electron microscopy external cell wall flattening was observed. This experiment assures the greatest $P$. maximum sensitivity to fluoride and reveals anatomic characteristics of $C$. gayana that can contribute for great resistance of this species to fluoride.
\end{abstract}

Key words - Anatomy, Poaceae, bioindicators, fluoride, pollution

\section{Introdução}

Dentre os poluentes atmosféricos, o flúor não é o de maior importância com relação aos danos provocados na vegetação de países desenvolvidos e em desenvolvimento, mas é o de maior fitotoxicidade, pois pode causar injúrias em espécies suscetíveis em concentrações atmosféricas 10 a 1.000 vezes menor (menos que $1 \mathrm{mg}^{-1}$ ) que outros poluentes, como o ozônio, o dióxido de enxofre e os óxidos de nitrogênio (Weinstein, 1977).

O flúor é encontrado na atmosfera principalmente na forma de ácido fluorídrico (HF) e é originado de fontes antropogênicas como as fundições de alumínio, a produção de adubos minerais, a fabricação de vidros e cerâmicas, dentre outras (Dobbs, 1974; Arndt et al., 1995).

Nas precipitações atmosféricas, a concentração de flúor varia de 1 a $1.000 \mathrm{mg} \mathrm{l}^{-1}$. Em áreas industriais, pode atingir $10 \mathrm{mg} \mathrm{l}^{-1}$, tendo em vista que o flúor gasoso é emitido sob formas prontamente hidrolisáveis (Smith \& Hodge, 1979).

Nas plantas, o flúor é absorvido principalmente pelas folhas. Na forma gasosa, penetra nos tecidos sobretudo através dos estômatos e, em menor proporção, pela cutícula (MILLER, 1993). Em solução, o flúor é absorvido por toda a superfície foliar (AZEVEDO, 1995), e move-se via apoplasto no interior da folha, chegando até as margens e o ápice por meio da corrente transpiratória, onde é acumulado, promovendo injúrias (Miller, 1993).

Figueiredo (1994) avaliou dez espécies de gramíneas tropicais quanto à sensibilidade ao flúor, através de dados visuais e bioquímicos, selecionando Panicum maximum Jacq. e Chloris gayana Kunth., utilizadas neste estudo, por apresentarem amplo espectro de sensibilidade e resistência, respectivamente.

Este trabalho teve como objetivos identificar as injúrias provocadas pelo flúor, dissolvido na água da chuva, na estrutura da lâmina foliar de gramíneas sensíveis e resistentes e fornecer subsídios para seleção de características diagnósticas a serem utilizadas na bioindicação desse elemento, como poluente atmosférico.

\section{Material e métodos}

Foram utilizadas neste estudo duas espécies de gramíneas (Poaceae): Panicum maximum Jacq. cv. (colonião) e Chloris gayana Kunth. (capim-rhodes).

Sementes de rhodes e colonião foram espalhadas em toda a superfície do solo em vasos plásticos com capacidade para $0,65 \mathrm{~kg}$, montados sobre recipientes com água $\mathrm{e}$ interligados por corda, segundo as recomendações de Rick \& Ardnt (1987).

Ao atingirem o estágio de quatro ou cinco folhas, as plantas foram submetidas a chuvas simuladas com solução de fluoreto de potássio, $15 \mathrm{mg} \mathrm{ml}^{-1}$, por 20 dias consecutivos. As chuvas tiveram duração diária de 15 minutos, e antes e depois de cada simulação as plantas permaneciam sob painel luminoso por no mínimo 15 minutos, para abertura dos estômatos. As plantas controle foram submetidas ao mesmo procedimento utilizandose água destilada no lugar da solução de fluoreto de potássio. 
Para simulação das chuvas foi utilizada a câmara construída e adaptada por Alves (1988), a partir do modelo proposto por Evans et al.(1977).

No final do experimento, folhas em expansão e totalmente expandidas foram coletadas, sendo parte fixada diretamente e armazenada em etanol $50 \%$, para posterior diafanização utilizando-se hidróxido de sódio a $10 \%$ e hipoclorito de sódio comercial a $50 \%$. Após a diafanização o material foi corado com fucsina e azul de astra e montado entre lâmina e lamínula com gelatina glicerinada. Segmentos das folhas coletadas foram fixados em FAA, desidratados em série butílica (Johansen, 1940) destinados à inclusão em parafina para cortes transversais em micrótomo com cerca de $15 \mathrm{~mm}$ de espessura.

Após a desparafinização, coloração com azul de astra e fucsina e desidratação os cortes foram montados em Entellan. O restante das folhas coletadas foi seca em estufa de ventilação forçada a $70^{\circ} \mathrm{C}$, para quantificação do fluoreto na matéria seca, utilizando-se ácido perclórico a $0,1 \mathrm{M}$ como extrator e um eletrodo específico (GarciaCiudad et al., 1985). Amostras da lâmina foliar, com aproximadamente $0,5 \mathrm{~cm}^{2}$, apresentando sintomas (clorose e necrose) também foram coletadas, fixadas em glutaraldeído a $3 \%$ e pós-fixadas com tetróxido de ósmio a $1 \%$, preparados com tampão fosfato de potássio (Milloning, 1961), para serem analisadas ao microscópio eletrônico de varredura.

O material destinado à microscopia eletrônica de varredura foi seco em ponto crítico de $\mathrm{CO}_{2}$, seguido pela fixação em suporte próprio e cobertura metálica com ouro.

As observações e a documentação fotográfica, foram feitas em fotomicroscópio (ZEISSDOCUVAL) e microscópio eletrônico de varredura (JEOL T200). As escalas foram feitas utilizando-se lâmina milimetrada.

\section{Resultados e discussão}

Sintomatologia - Ao final do experimento, $P$. maximum apresentou todas as folhas tratadas mais amareladas que as do controle.

As injúrias identificadas em $P$. maximum foram caracterizadas como clorose, início de necrose e necrose, localizadas principalmente nas margens e ápices da lâmina foliar, sendo também estes os principais sintomas observados em outras monocotiledôneas submetidas à poluição por fluoretos na atmosfera (Weinstein, 1977; Conover \& Poole, 1982; Sun \& Su 1985; Arndt et al., 1995).

Uma maior proporção de folhas em expansão apresentou sintomas visíveis ao final do tratamento quando comparadas às folhas totalmente expandidas.

A presença do maior número de folhas afetadas pelo flúor, associada ao fato de as folhas em expansão terem apresentado menor concentração desse elemento nos tecidos (Tab.1), sugere que as folhas mais novas foram mais sensíveis ao flúor dissolvido na água de chuva simulada do que as folhas mais velhas. A maior sensibilidade das folhas jovens foi também constatada por Azevedo (1995) para folhas de Glycine max (soja), tendo observado que baixas concentrações foram suficientes para danificar folhas jovens. A resposta das plantas aos poluentes varia com o seu estádio de desenvolvimento, entre outros fatores, sendo as mais jovens, recém-expandidas ou próximas à total expansão, mais sensíveis (Kozlowski, 1980).

Observou-se que nas folhas em expansão prevaleceram clorose nas margens e início de necrose no ápice, enquanto nas folhas totalmente expandidas prevaleceram clorose, próximo à nervura central e necrose marginal e apical, sugerindo a evolução da clorose à necrose, na margem da lâmina foliar. Wei \& Miller (1972) observaram que áreas cloróticas, ocorrentes em folhas de Glycine max fumigadas com fluoreto de hidrogênio $(\mathrm{FH})$, tornaram-se necróticas e que 
o aumento da concentração desse poluente não alterou o tipo de injúria, mas influenciou a sua taxa de desenvolvimento.

C. gayana não mostrou diferenças quanto à coloração entre plantas tratadas e do controle e o principal sintoma observado foi o enrugamento da lâmina foliar.

Ondulações na superfície das folhas, juntamente à clorose e necrose nos ápices e nas margens, foram também citadas por Garber (1973) como sintomas do $\mathrm{F}^{-}$nas plantas.

Clorose, vista como pontos esbranquiçados próximo à nervura central no meio e na base da lâmina foliar, início de necrose e necrose marginal, em especial na base da lâmina, foram também observadas em C. gayana.

Ocorrência de necrose na base das folhas de Pinus fumigadas com FH foi também registrada por Edmund Junior \& Alstad (1985), mas a sua presença não foi atribuída à concentração de flúor nos tecidos e sim ao acúmulo de partículas na base do fascículo. Em virtude da disposição mais vertical da folha de C. gayana, o que sugere maior acúmulo da água da chuva na base da lâmina foliar, as injúrias basais podem ser atribuídas ao maior tempo de contato do poluente com a superfície da folha, principalmente no lado adaxial.

Teor de flúor na matéria seca - Analisando a concentração do flúor nos tecidos, no final do experimento (Tab.1), nota-se que $P$. maximum apresentou alto teor desse íon, nas amostras submetidas à chuva de $15 \mathrm{mg} \mathrm{ml}^{-1}$. As folhas totalmente expandidas mostraram possuir cerca de três vezes mais flúor na matéria seca do que as folhas em expansão, o que indica a acumulação desse poluente nos tecidos. Segundo Coulter et al. (1985), o flúor se acumula nos tecidos na forma solúvel e inorgânica $\left(\mathrm{F}^{-}\right)$, causando lesões quando concentrações letais são atingidas sendo, portanto, um poluente cuja injúria tem natureza cumulativa. Em C. gayana, a concentração de flúor também foi mais alta nas folhas totalmente expandidas. C. gayana apresentou, no entanto, menor concentração de flúor nos tecidos do que $P$. maximum. Por acumular altas concentrações de $\mathrm{F}^{-}$, principalmente nas folhas em estádio mais avançado de desenvolvimento, $P$. maximum pode ser considerada, além de uma ótima bioindicadora de reação, uma eficiente bioindicadora de acumulação, enquanto $C$. gayana também por acumular altas concentrações de $\mathrm{F}^{-}$, pode ser utilizada na bioindicação da poluição por flúor como uma espécie acumuladora, como anteriormente citado por Figueiredo (1994).

Efeitos do flúor na estrutura da lâmina foliar P. maximum - Nas folhas diafanizadas, as regiões da lâmina que foram afetadas pelo flúor coraram-se fortemente pela fucsina, sendo possível distinguir e delimitar facilmente as áreas injuriadas (Fig. 1). Adams et al. (1984) também registraram a ocorrência de lesões cujas células coram-se densamente pela safranina em folhas de Artemisia tilesii diafanizadas, à semelhança do observado para P. maximum.

Tabela 1. Valores médios da concentração de flúor ( $\mathrm{mg} \mathrm{g}^{-1}$ de matéria seca) na lâmina foliar de Panicum maximum e Chloris gayana, 24 horas após a última chuva com fluoreto de potássio $\left(\mathrm{F}^{-}\right)$.

\begin{tabular}{lllll}
\hline Tratamento & \multicolumn{2}{c}{$0 \mu \mathrm{g} \mathrm{ml}^{-1} \mathrm{de} \mathrm{F}^{-}$} & \multicolumn{2}{c}{$15 \mu \mathrm{g} \mathrm{ml}^{-1} \mathrm{de} \mathrm{F}^{-}$} \\
\cline { 2 - 5 } & $\mathrm{FN}$ & $\mathrm{FD}$ & $\mathrm{FN}$ & $\mathrm{FD}$ \\
\hline C. gayana & - & 20,2 & 95,0 & 230,0 \\
$P$. maximum & - & 9,2 & 274,7 & 605,0 \\
\hline
\end{tabular}

FN - Folha em expansão.

FD - Folha totalmente expandida. 
A coloração intensa pela fucsina é atribuída ao acúmulo de compostos fenólicos, como comprovado, por meio de reações histoquímicas, por Zobel \& Nighswander (1991), em áreas necróticas de folhas de Pinus submetidas à chuva ácida.

Figueiredo (1994) verificou que em $P$. maximum o teor de fenóis totais aumentou com o incremento de flúor, tendo as plantas tratadas acumulado $80 \%$ mais fenóis que as plantas do controle. $\mathrm{O}$ acúmulo de compostos fenólicos é um mecanismo de defesa das plantas ativado por fatores bióticos e abióticos que induzem ao estresse (Vaughn \& Duke, 1984).

As alterações provocadas pelo flúor nas paredes e a plasmólise nas células da epiderme podem levar a diferentes tipos de lesões (Fig. 2, 3 e 4). Algumas vezes não se observa a presença da epiderme em grandes áreas da superfície da
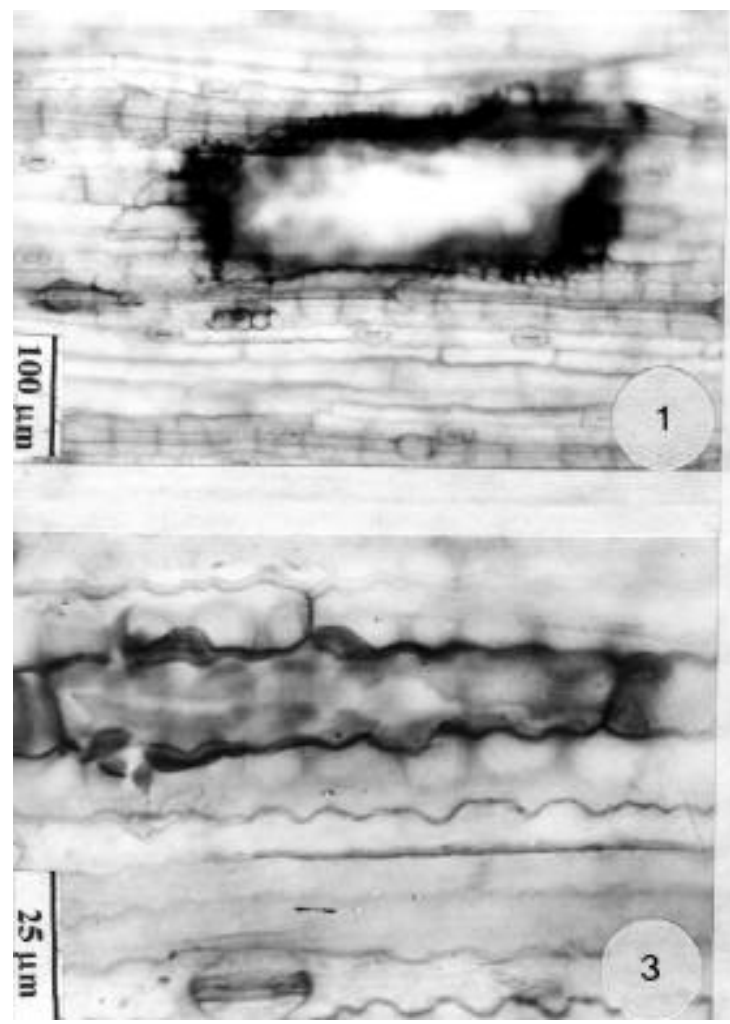

lâmina foliar, e as células do mesofilo rompemse, juntamente com a epiderme, formando uma grande erosão (Fig. 1). Para Adams et al. (1984), o colapso das células epidérmicas pode estar associado a alterações na permeabilidade das células. A separação entre as células, como observado em P. maximum (Fig. 2) pode ser resultado da dissolução da lamela média, tendo sido esta descrita como uma alteração evidente, provocada pelo $\mathrm{FH}$ gasoso, na estrutura de Glycine max (Wei \& Miller,1972).

Constatou-se que a ocorrência das lesões coincidiu com a dos estômatos (Fig. 4), tendo sido verificada, em menor freqüência, a presença dessas junto aos tricomas.

Adams et al. (1984), em folhas de Artemisia submetidas à chuva ácida, assim como Azevedo (1995), em folhas de soja submetidas a chuvas com $\mathrm{F}^{-}$, observaram a presença de estômatos com

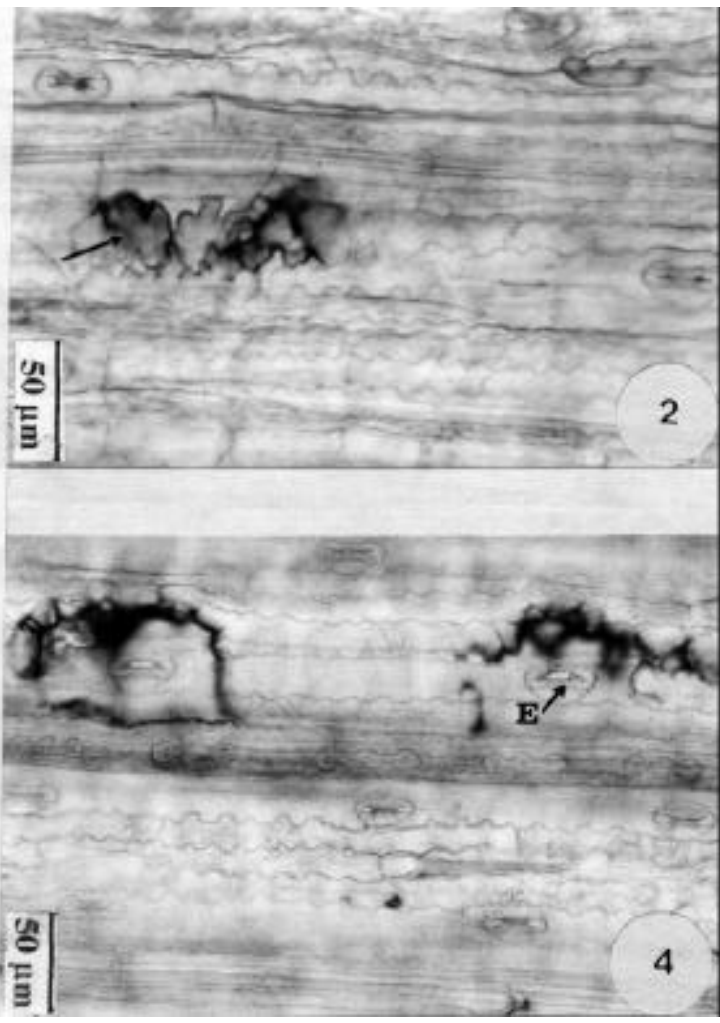

Fig. 1 a 4. Panicum maximum - secções da lâmina foliar diafanizada. 1- área injuriada na epiderme adaxial; 2 - células epidérmicas fragmentadas $(\rightarrow) ; 3$ - células epidérmicas com parede periclinal externa arrebantada; 4 - lesões nas células epidérmicas adjacentes aos estômatos (E). 
ostíolo aberto, como foi também verificado nas áreas adjacentes às lesões em $P$. maximum.

Nos cortes transversais da lâmina foliar de $P$. maximum tratadas com $\mathrm{F}^{-}$, principalmente naquelas em que ocorreu clorose, verificou-se que os cloroplastos das células do mesofilo, nas plantas do controle localizam-se na região da célula próximo à epiderme, encontram-se dispersos, em número e tamanho reduzidos. Os cloroplastos das células da bainha também mostraram-se com tamanho e número reduzidos (Fig. 5 e 6). A alteração na forma e a dispersão dos cloroplastos foram também citadas por Wei \& Miller (1972) para folhas de Glycine max submetidas a $\mathrm{FH}$.

Em plantas onde foi observada clorose marginal, constatou-se que as células da epiderme, do mesofilo e da bainha dos feixes encontravamse plasmolisadas com dobras nas paredes. $\mathrm{O}$ conteúdo celular também se altera e ocorre a desintegração dos cloroplastos. Em fase mais adiantada da injúria, todo o conteúdo citoplasmático se desintegra (Fig. 7).

$\mathrm{Na}$ região da lâmina foliar necrosada, as células do mesofilo se desintegram totalmente, formando entre as duas faces da epiderme uma massa compacta (Fig.7 e 8) que se cora de vermelho pela fucsina. Pôde ser observado que a necrose se inicia nas células da epiderme, tanto na face abaxial como adaxial, se acentua nas células do mesofilo com a desintegração do conteúdo celular, estende-se às células da bainha e só depois ao floema e, por último, ao xilema. Os pêlos tectores vistos nas regiões necrosadas freqüentemente estão intactos (Fig.8).

Para Wei \& Miller (1972), o primeiro sítio de injúria do fluoreto é o tonoplasto, devendo-se ressaltar que esse elemento remove o cálcio e o magnésio da membrana, alterando sua permeabilidade. O rompimento do tonoplasto leva à desintegração do citoplasma e de organelas.

Solberg \& Adams (1956) registraram, entre outros fatores, a espessura da parede das células como um fator que influenciou o grau de injúria

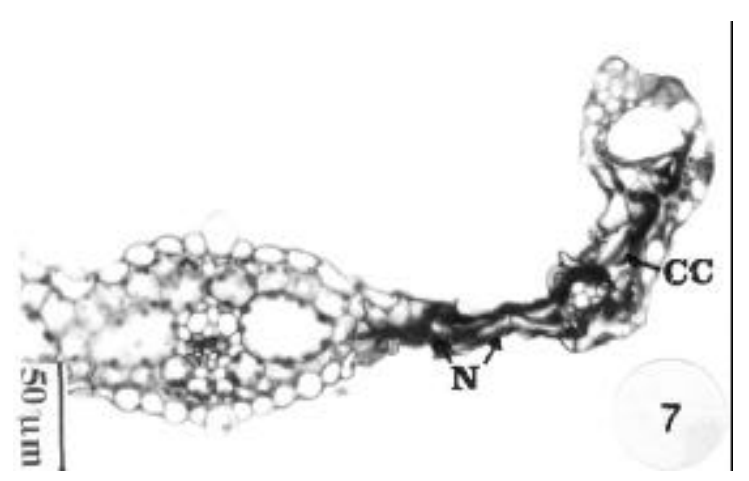

das folhas por fitotóxicos. Eles observaram que o tecido vascular mostrou menores injúrias que outros tecidos em folhas de árvores frutíferas fumigadas com $\mathrm{FH}$.

Em Coleus fumigados com fluoreto, Lamprecht Junior \& Powell (1977) observaram que o mesofilo foi afetado antes da epiderme adaxial. Neste trabalho, tal fato foi particularmente observado na margem da folha com o início da necrose, mas as injúrias também iniciaram-se na epiderme, sendo mais freqüentes na face adaxial, onde o rompimento das células necrosadas deixam expostas as células do mesofilo, que também serão injuriadas, resultando em erosões de diferentes proporções na superfície da lâmina foliar (Fig. 9 e 10).

$\mathrm{O}$ tratamento com $\mathrm{F}^{-}$também provocou hipertrofia das células do mesofilo, levando ao arranjo desordenado deste e à projeção de células nas duas superfícies da folha (Fig. 11 e 12). Esse tipo de lesão foi mais frequiente nas folhas em expansão, sugerindo que ela pode estar associada a baixas concentrações de flúor nos tecidos, além do menor espessamento das paredes das células. Em folhas totalmente expandidas, os sintomas são mais agudos e a necrose é preferencialmente visualizada. Stewart et al. (1973), estudando as características anatômicas em coníferas submetidas à poluição por flúor, observaram hipertrofia nas células epiteliais dos canais de resina e nas células parenquimáticas 

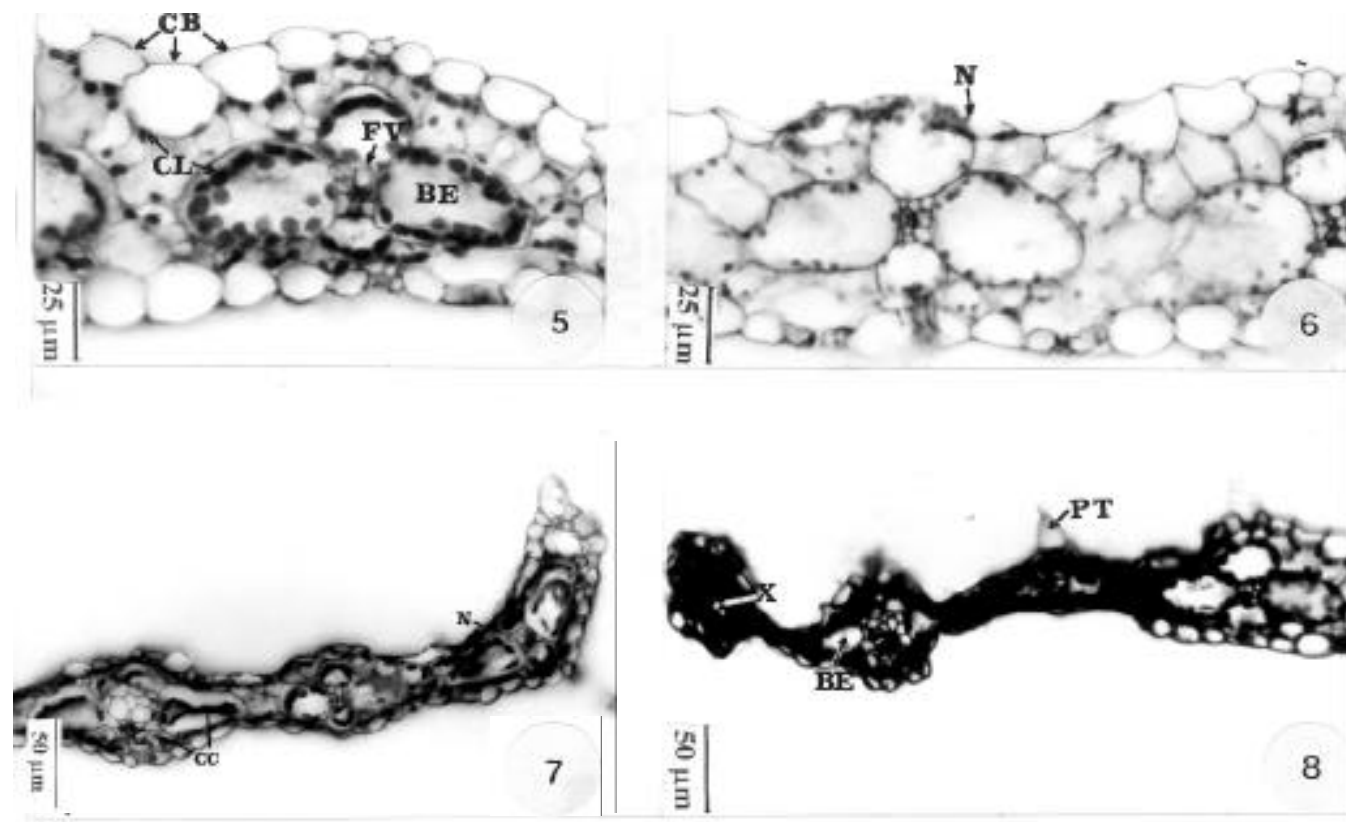

$\frac{\text { हn }}{\mathrm{E}}$
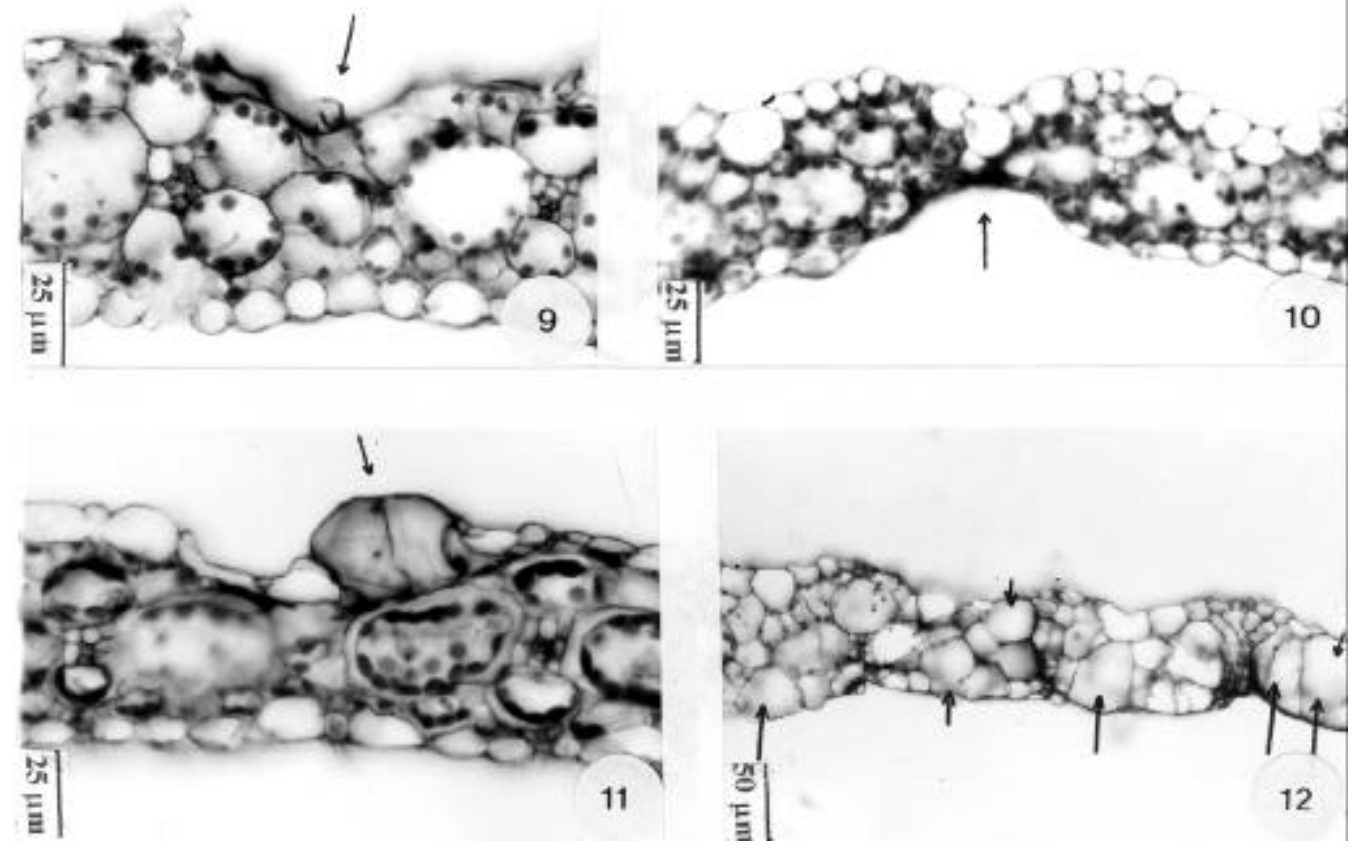

Figura 5 a 12. Panicum maximum - Cortes tranversais da lâmina foliar. 5 - planta do controle; 6 - planta tratada com F envidenciando área clorótica com alteração no tamanho, número e disposição dos cloroplastos e necrose na epiderme adaxial; 7 - margem da lâmina foliar com clorose e ínicio de necrose evidenciando conteúdo citoplasmático reunido no interior das células; 8 - margem da lâmina celular necrosada; 9 - lâmina foliar evidenciando rompimento das células necrosadas na epiderme adaxial $(\rightarrow)$; 11 - lâmina foliar evidenciando hipertrofia nas células do mesofilo $(\rightarrow)$; 12 - lâmina foliar mostrando o arranjo desordenado dos tecidos resultantes de hipertrofia $(\rightarrow)$ e necrose das células. (CB) células buliformes, (CL) cloroplastos (BE) bainha de feixe vascular, (FV) feixe vascular, (N) necrose, (CC) conteúdo celular, $(\mathrm{X})$ xilema, (PT) pêlo tector; 
do floema, concluindo que doses menores deste poluente acumulam-se gradualmente, causando esse tipo de injúria, enquanto doses maiores causam lesões mais severas.

C. gayana - Na lâmina foliar diafanizada, foi também possível distinguir as áreas onde ocorreram as lesões por meio da coloração com fucsina indicando a presença de compostos fenólicos, como já discutido anteriormente. Figueiredo (1994), evidenciou, em C. gayana $25 \%$ mais fenóis nas plantas tratadas que nas testemunhas, sendo essa concentração menor que a verificada em $P$. maximum. A ocorrência de fenóis em $C$. gayana comprova a presença de injúrias na folha, mesmo em ausência de sintomas visíveis, pois compostos fenólicos, como citado por Vaughn \& Duke, (1984) são comumente associados ao mecanismo de defesa das plantas a fatores estressantes. $\mathrm{O}$ aumento na quantidade de compostos fenólicos presentes nos tecidos com a progressão da injúria foi também registrado por Hasemann et al. (1990) em Picea abies.

As injúrias nessa espécie foram preferencialmente observadas próximo às margens da lâmina foliar (Fig. 13), enquanto em $P$. maximum elas foram encontradas, além da margem, distribuídas em toda a lâmina. Assim como em $P$. maximum, a maior proporção de lesões também ocorreu na face adaxial, o que pode ser atribuído, conforme Alves \& Oliva Cano (1993), ao impacto direto das gotas de chuva sobre essa face da epiderme.

Além do conteúdo e das paredes coradas, áreas onde as células da epiderme e do mesofilo possuíam as paredes periclinais externas rompidas foram visualizadas em algumas regiões da superfície foliar formando erosões (Fig. 14) como as observadas em $P$. maximum.

Pela facilidade da técnica e da observação de áreas injuriadas coradas pela fucsina nas duas espécies estudadas, a diafanização revelou-se um procedimento passível de ser utilizado na bioindicação de poluentes atmosféricos.
Na lâmina foliar de C. gayana em corte transversal foram reproduzidos alguns dos sintomas observados em $P$. maximum, mas em menor proporção, como: plasmólise com alterações das paredes e necrose da epiderme, passando às células adjacentes; erosões nas superfícies das folhas; desintegração do conteúdo celular nas células do mesofilo resultando em constrições pontuais e necrose nas margens (Fig. 15, 16, 17 e 18). As lesões observadas nas células da epiderme, faces adaxial e abaxial, foram também preferencialmente localizadas junto aos feixes vasculares em regiões coincidentes com a localização dos estômatos (Fig. 17).

Hipertrofia e alterações nos cloroplastos não foram evidentes em C. gayana. Nesta espécie, no entanto, não foi detectada a ocorrência de clorose generalizada, como em $P$. maximum, sendo as injúrias bastante restritas e delimitadas a pontos nas folhas.

Microscopia eletrônica de varredura - Ao microscópio eletrônico de varredura (MEV) foram constatadas alterações na superfície epidérmica de plantas tratadas, quando comparadas com as plantas controle, em $P$. maximum (Fig. 19 a 22) e em C. gayana (Fig. 23 a 28). Notou-se que ocorreu a perda da turgidez, com achatamento da superfície das células e perda da cera epicuticular nas regiões afetadas pelo flúor (Fig. 21, 22, 26 e 28), nas duas espécies estudadas o que também foi observado por Azevedo (1995) em folhas de soja tratadas com flúor em solução.

Apesar das lesões próximas aos tricomas (Fig. 22, 26 e 28) observados ao microscópio eletrônico de varredura, a ocorrência de injurias foi verificada preferencialmente próximo aos estômatos (Fig. 21) nas duas espécies estudadas, o que leva a concluir que eles constituem a principal via de entrada do flúor nessas espécies. Para Pushnik \& Miller (1990), o flúor não se distribui uniformemente na folha, tendendo a se acumular nas áreas próximo ao ponto de entrada, onde ocorrerão maiores danos. 

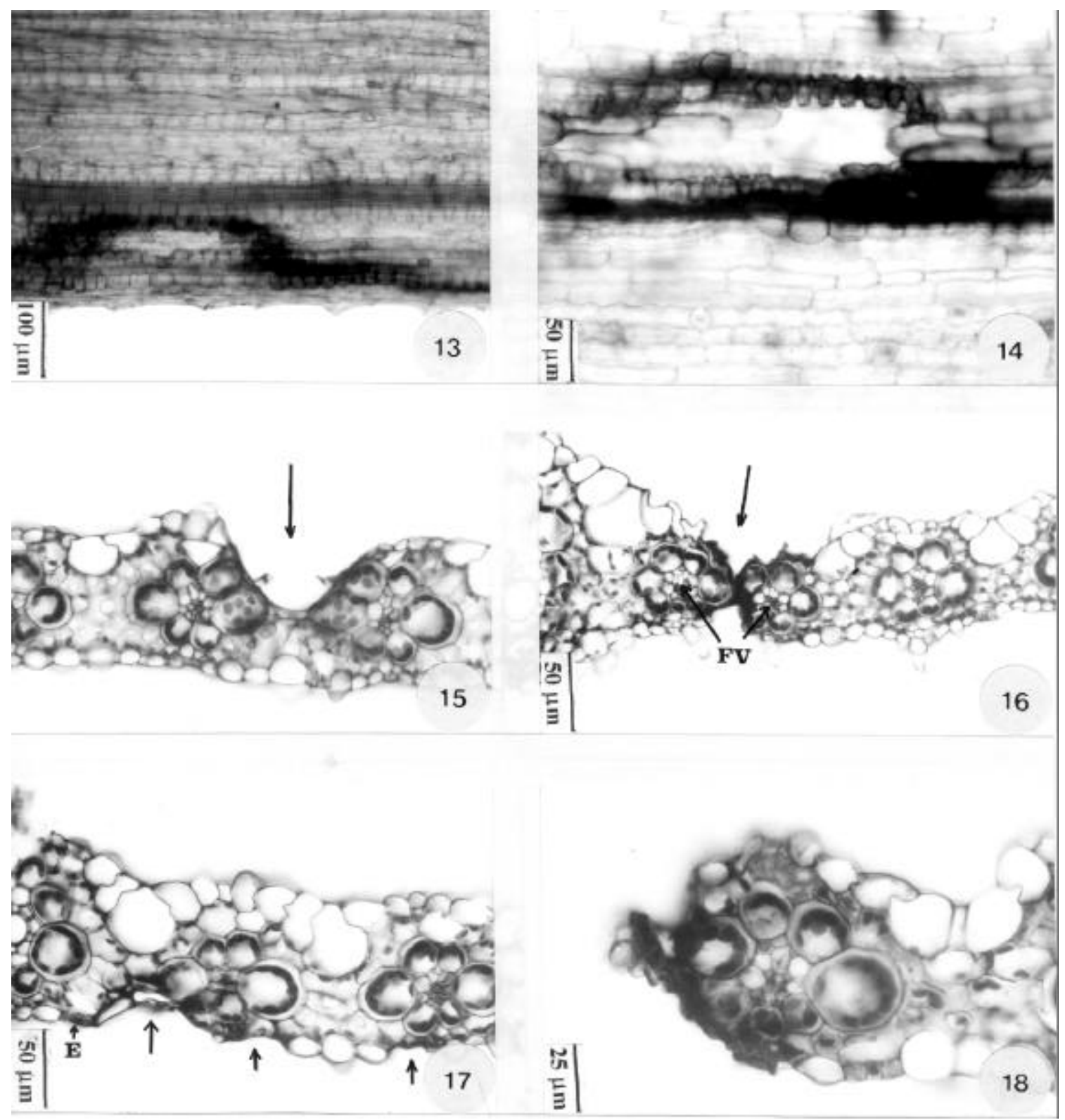

Figura 13 a 18. Chloris gayana - 13 - margem da lâmina foliar evidenciando lesões (áreas negras); 14 - lâmina foliar diafanizada evidenciado erosão na epiderme; 15 - corte transversal da lâmina foliar evidenciando necrose e rompimento das células na epiderme adaxial $(\rightarrow)$; 16 - corte tranversal da lâmina foliar envidenciando necrose $(\rightarrow)$; dos tecidos entre dois feixes vasculares $(\mathrm{FV}) ; 17$ - corte transversal da lâmina foliar evidenciando lesões $(\rightarrow)$ na epiderme abaxial próximo aos estômatos (E); 18 - corte tranversal de lâmina foliar evidenciando necrose dos tecidos na margem da folha.

A presença de uma superfície foliar mais sinuosa, o maior número de macropêlos e proporção de cera epicuticular em $C$. gayana quando comparada com $P$. maximum são características que podem estar contribuindo para a maior resistência dessa espécie ao $\mathrm{F}^{-}$dissolvido na água da chuva. Garg \& Varshney (1980) comentaram que variedades de Petunia resistentes à poluição possuem maior densidade de tricomas. Baker \& Hunt (1981) relataram que 

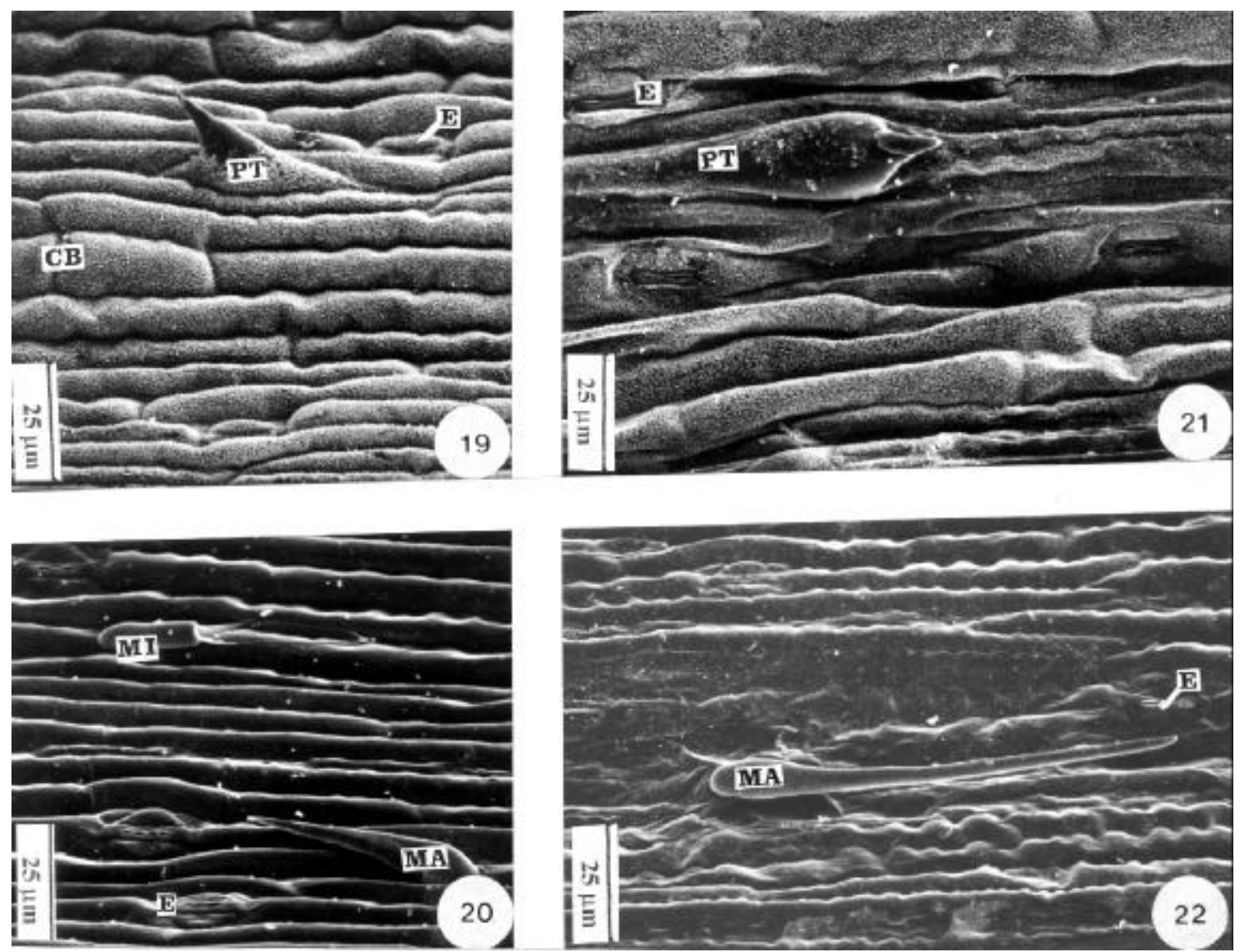

Figura 19 a 22. Panicum maximum - Superfície da lâmina foliar vista ao MEV: 19 - epiderme adaxial de plantas do controle; 20 - epiderme abaxial de plantas do controle; 21 - epiderme abaxial de plantas tratadas com $\mathrm{F}^{-}$evidenciando perda de turgidez das células sobre e adjacente às nervuras, coincidentes com a localização dos estômatos; 22 - perda de turgidez e achatamento das células na superdície abaxial da lâmina foliar de plantas tratadas com F; (E) estômato, (MA) macropêlo, (CB) células buliformes, (MI) micropêlo, (PT) pêlo tector.

características superficiais como tricomas, cutículas e cera são importantes para determinar a capacidade de umedecimento, a permeabilidade, a penetração e as trocas das plantas com a atmosfera.

\section{Referências Bibliográficas}

Adams, C.M.; Dengler, N.G. \& Hutchinson, T.C. 1984. Acid rain effects on foliar histology of Artemisia tilesii. Can. J. Bot. 62: 463-474.

Alves, P.L.C.A. 1988. Efeitos nutricionais, fisiológicos e bioquímicos da chuva ácida simulada e do latossolo vermelho-amarelo de Cubatão-SP, em soja (Glycine max L.) Merril .
Tese de Mestrado. Universidade Federal de Viçosa, Viçosa. 144p.

Alves, P.L.C.A. \& Oliva Cano, M.A. 1993. Reações da soja a chuva ácida e solo contaminado. Ambiente 7 (1): 34-39.

Arndt, U., Flores, F., Weinstein, L. 1995. Efeitos do flúor sobre as plantas: diagnose de danos na vegetação do Brasil. Ed. UFRGS, Porto Alegre.

Azevedo, A.A. 1995. Ação do flúor, em chuva simulada, sobre a estrutura foliar de Glycine max (L.) Merril. Tese de Doutorado. Universidade de São Paulo, São Paulo. 95p.

Baker, E.A. \& Hunt, G.M. 1981. Developmental changes in leaf epicuticular waxes in relation to foliar penetration. New Phytol. 88: 731-747.

Conover, C.A. \& Poole, R.T. 1982. Fluoride induced 

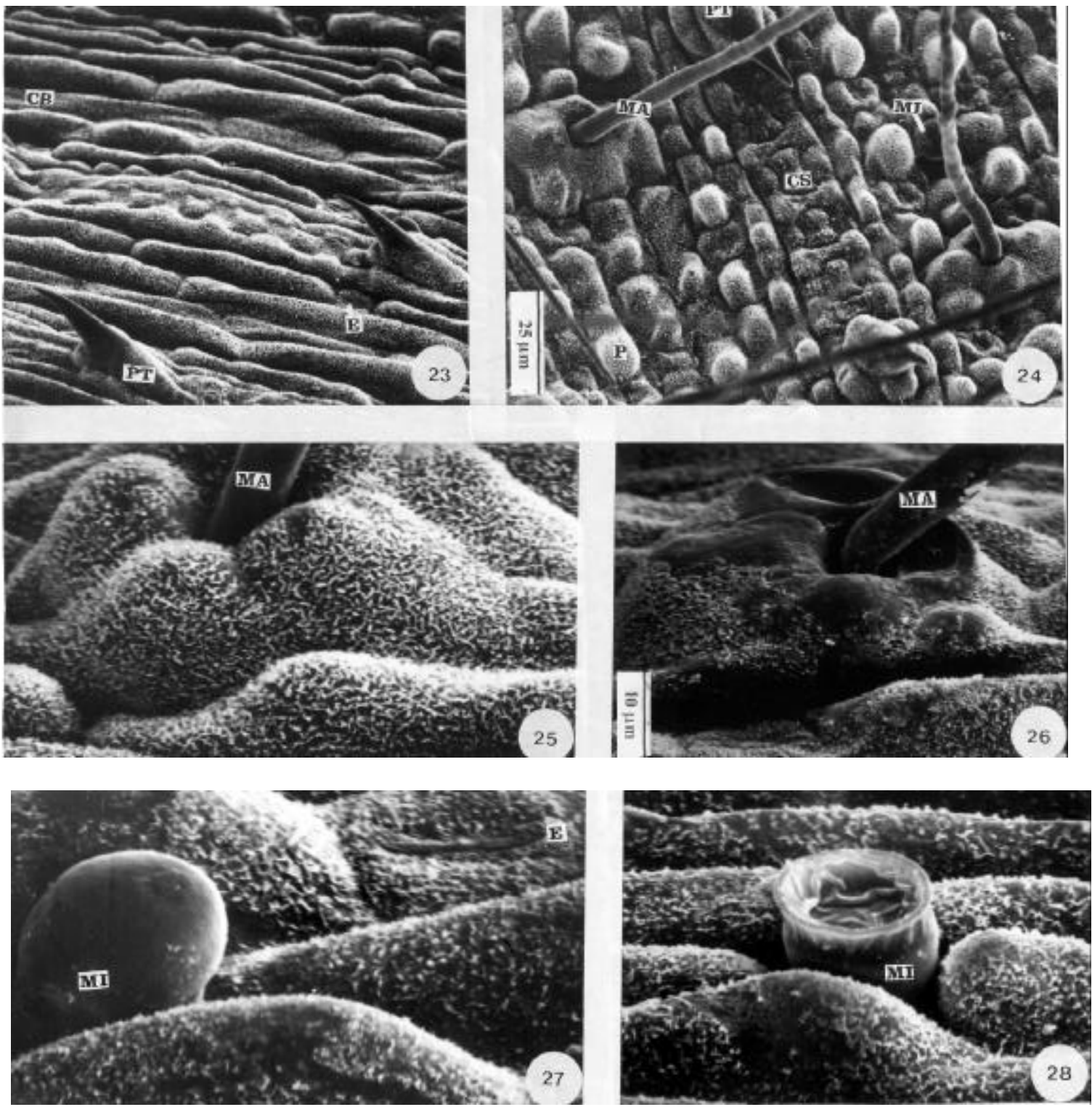

Figura 23 a 28. Chloris gayana - Superfície da lâmina foliar vista ao MEV; 23 - epiderme adaxial do controle; 24 epiderme abaxial de plantas do controle; 25 - detalhe das células epidérmicas da base do macropêlo na superfície abaxial de plantas do controle; 26 - detalhe das células epidérmicas da base do macropêlo na superfície abaxial de plantas com F evidenciando a perda da cera epicuticular e da turgidez; 27 - detalhe de um micropêlo na epiderme abaxial da lâmina foliar de plantas do controle; 28 - detalhe de um micropêlo na epiderme abaxial da lâmina foliar de plantas tratadas com Fevidenciando alterações na turgidez da célula distal. (PT) pêlo tector, (CB) célula buliforme, (CS) corpos de sílica; (MI) micropêlo, (P) papila, (E) estômato.

chlorosis and necrosis of Dracaena fragrans "massangeana". J. Amer. Soc. Hort. Sci. 107 (1): 136-139.

Coulter C.T.; Pack, M.R. \& Sulzbach, C.W. 1985. An evaluation of the dose-response relationship of fluoride injury to Gladiolus. Atmosph. Environ. 19 (6): 1001-1007.

Dobbs, C.G. 1974. Fluoride and the environment. Fluoride 7 (3): 123-135.

Edmund Junior, G.F. \& Alstad, D.N. 1985. Incidence 
of basal needle necrosis of pines in relation to environmental factors. Environ. Pollut. Ser. A. 37 :217-227.

Evans, L.S., Gmur, N.F., Costa, F. 1977. Leaf surface and histological perturbations of leaves of Phaseolus vulgaris and Helianthus annuus after exposure to simulated acid rain. Amer. J. Bot. 64 (7): 903-913.

Figueiredo, J.G. 1994. Avaliação de gramíneas tropicais como bioindicadoras da presença do flúor. Tese de Mestrado. Universidade Federal de Viçosa, Viçosa. 87p.

Garber, K. 1973.The differential diagnosis of fluoride damage to plants. Fluoride 6 (1): 33-40.

Garcia-Ciudad, A.; Garcia-Criado, B. \& Emeterio, C. P. 1985. Determination of fluoride in plant samples by a potenciometric method and near-infrared reflectance spectroscopy. Commun. Soil Sci. Plant Anal. 16 (10):1107-1122.

Garg, K.K. \& Varshney, C.K. 1980. Effect of air pollution on the leaf epidermis at the submicroscopic level. Experientia 36: 1364-1366.

Hasemann, G.; Jung, G. \& Wild, A. 1990. The loss of structural integrity in damaged spruce needles from locations exposed to air pollution. II. Epidermis and stomata (dermal tissue). J. Phytopathol. 128: 33-45.

Johansen, D.A. 1940. Plant Microtechnique. McGraw Hill Book, New York.

Kozlowski, T.T. 1980. Impacts of air pollution on forest ecosystems. Bioscience 30 (2): 89-93.

Lamprecht Junior, W.O. \& Powell, R.D. 1977. The effect of hydrogen fluoride on two pigments in Coleus. Econ. Bot. 31: 148-152.

Miller, G.W. 1993. The effect of fluoride on higher plants. Fluoride 26 (1).3-22.

Milloning, G. 1961. Advantages of a phosphate buffer for $\mathrm{OsO}_{4}$ solutions in fixation. J. Appl. Physiol. 32: 1637.

Pushnik, J.C. \& Miller, G.W. 1990. The influences of elevated environmental fluoride on the physiology and metabolism of higher plants. Fluoride 23 (1): 5-19.

Rick, R.K. \& Ardnt, U. 1987. Methodische Untersuchungen Zur Optimierung des Verfahrens der Standardisierten Graskultr In: VEREIN DEUTSCHER INGENIEURE - VDI. Bioindikation. S.I: 301-316. (VDI - Berichte, 609).

Smith, F.A. \& Hodge, H.C. 1979. Airbone fluorides and man: Part 1. CRC Crit. Rev. Environ. Control 8: $293-372$.

Solberg, R.A. \& Adams, D.F. 1956. Histological responses of some plant leaves to hydrogen fluoride and sulfur dioxide. Amer. J. Bot. 43: 755-760.

Stewart, D., Treshow, M., Harner, F.M. 1973. Pathological anatomy of conifer needle necrosis. Can. J. Bot. 51: 984-988.

Sun, E.J. \& Su, H.J. 1985. Fluoride injury to rice plants caused by air pollution emitted from ceramic and brick factories. Environ. Pollut. Ser. A 37: 335-342.

Vaughn, K. \& Duke, S.O. 1984. Function of polyphenol oxidase in higher plants. Physiol. Plan 60 (1): 106-112.

Wei, L. \& Miller, G.W. 1972. Effect of HF on the fine structure of mesophyll cells from Glycine max, Merr. Fluoride 5 (2): 67-72.

Weinstein, L.H. 1977 . Fluoride and plant life . J. Occup. Med. 19 (1): 49-78.

Zobel, A. \& Nighswander, J.E. 1991. Accumulation of phenolic compounds in the necrotic areas of Austrian and red pine needles after spraying with sulphuric acid: a possible bioindicator of air pollution. New Phytol. 117: .565-574. 